\title{
LA MEMORIAY LA IMAGINACIÓN EN LAS NARRACIONES BREVES DE NABOKOV
}

\author{
Asunción Barreras Gómez \\ Universidad de La Rioja
}

RESU MEN: Después de la revolución bolchevique, la familia de Nabokov tuvo que abandonar su Rusia natal. Este hecho influyó la obra literaria del autor. Hay un sentimiento de pérdida del sentido del tiempo y un sentimiento de pérdida de todo aquello relacionado con la vieja Rusia. Sin embargo, Vladimir Nabokov no es un autor autobiográfico. No se muestra nostálgico por su patria en su obra. El escritor mezcla la imaginación y la memoria en un intento de recuperar el pasado. Además, defamiliariza las convenciones narratológicas para distanciarse de lo que narra. Su ironía es otra forma de superar su pasado y, sobre todo, es otra forma de jugar con el lector.

ABSTRACT: After the Bolshevik revolution, Nabokov's family was forced to leave Russia. This fact influenced the writer's literary work. There is a feeling of loss of the sense of time and a feeling of loss of all those things related to the old Russia. However, Vladimir Nabokov is not an autobiographical author. He is not just longing nostagically for his native land in his work. He mixes imagination and memories in an attempt to capture the past. M oreover, he defamiliarizes the narratological conventions as a way to detach himself from what he tells. His irony is another way of coming to terms with his past, and, above all, another way of playing with the reader.

PALABRAS CLAVE: pasado, narrador, imaginación, verdad, ironía, autobiografía.

KEYWORDS: past, narrator, imagination, truth, irony, autobiography.

\section{Introducción}

El exilio es una característica importante en la vida de Nabokov. De hecho, se trata de un escritor estadounidense, cuyas raíces pertenecen a la Rusia prerrevolucionaria que tuvo que abandonar en su juventud. Cuando los bolcheviques tomaron el poder de Rusia Nabokov y su familia tuvieron que salir del país. Su nueva vida empezó en Berlín donde la comunidad de rusos expatriados, que no podían volver a su tierra natal por sus ideas políticas, mantenían sus memorias, cultura, lenguaje y costumbres en sus guetos rusos. 
Casi todas Ias narraciones breves de Nabokov, aunque varían en forma y estilo, tienen en común un tema: la pérdida cultural y psicológica de su tierra natal, unas veces tiene forma laberíntica, como en "The Visit to the M useum", y en otras toma forma en la pérdida de un amor, como sucede en "Spring in Fialta," "A M atter of Chance" o "The R eturn of Chrob."

En la obra literaria de $\mathrm{N}$ abokov encontramos muchos ejemplos que muestran la importancia del pasado, la memoria y la imaginación. Puede haber influido también el intenso interés que la madre de Nabokov y su tío Ruka sentían por los temas del pasado y la memoria y que Stegner (1966: 8) asegura que heredó el autor. M uchos críticos, como Rowe (1971: 162), Quennel (1979: 48), Roth (1982: 50), Shloss (1982: 225) o L ong (1984: 26) resaltan la importancia de la memoria y la imaginación en la obra de Nabokov. En concreto, Nicol y Barabtarlo (1993: XIV) afirman, retomando palabras del autor: "in Nabokov's world imagination is a form of memory," así sucede con varios relatos, como "First Love," "M ademoiselle 0," "The A dmiralty Spire" o "A Spring In Fialta," y en su primera novela M ary. ${ }^{1}$ En estos ejemplos los narradores nos hablan de sus experiencias y amores anteriores. El primero está basado en un amor de niñez en la costa francesa, el segundo en su institutriz y los otros están basados en Tamara, el primer amor juvenil de Nabokov en Rusia (Tolstaia y M eilakh 1995: 654). Son recuerdos, sucesos pasados que el autor transforma en pinceladas de sus obras de arte.

\section{L a importancia del pasado en el arte}

A I hablar de la selección artística el autor ya destaca la importancia del pasado en el arte, por lo que comenta:

The past is a constant accumulation of images, but our brain is not an ideal organ for constant retrospection and the best we can do is to pick out and try to retain those patches of rainbow light flitting through memory. The act of retention is the act of art, artistic selection, artistic blending, artistic re-combination of actual events... The good memorist, on the other hand, does his best to pre-

1. En la entrevista que A Iden W hitman le hizo a Nabokov en A bril de 1971 el autor reconoce que el amor de Ganin, el protagonista de Mary, y el primer amor del autor en 1915 tienen muchos aspectos en común (Nabokov 1990: 179). A demás N abokov utilizó cartas real es que se habían mandado Valentina Evgnievna, su amor en Rusia, y él en la novela (Boyd 1993 a: 146). Esta novela fue la primera de Nabokov en la que exhortizó ese amor ruso de juventud así B Boyd (1993 a: 245) comenta que esta novela era: the sheer relief for a young writer of 'getting rid of oneself.'" 
serve the utmost truth of the detail. One of the ways he achieves his intent is to find the right spot on his canvas for placing the right patch of remembered color. (Nabokov 1990: 186)

El pasado es un cúmulo de imágenes, su recuerdo es una creación artística y el que invoca ese pasado quiere mostrarlo fielmente. En este cita ${ }^{2}$ se aprecia una idea que también vuelve a destacar Nabokov (1987: 357) al analizar Du côté de chez Swann de M arcel Proust en su Curso de literatura europea.

L a obra más importante de las que tienen que ver con el pasado del autor es Speak, M emory, en la que Nabokov relata sus propias memorias y de la que dos de sus relatos se desprenden: "First L ove" y "M ademoiselle 0 ." R esulta especialmente interesante de destacar "M ademoiselle 0", ${ }^{3}$ ya que B urt Foster ${ }^{4}$ (1993: 111) resalta el hecho de que en "M ademoiselle 0 " exista una ambivalencia entre ser autobiográfica o ficticia, puesto que fue reescrita varias veces ${ }^{5}$, dependiendo del punto de vista que tenía N abokov sobre su concepto de escribir y de ser artista de la memoria.

\section{Recuperando el pasado: Una aproximación a "M ademoiselle 0 "}

A principios de enero de 1936 se planteó escribir un relato que se basara en su institutriz de la niñez (Boyd 1993: 422) y surgió "M ademoiselle 0". En esta narración breve encontramos a un narrador que se muestra consciente de utilizar la forma autobiográfica para relatar sus memorias:

2. A specto que nos recuerda el cuadro de Lily B ricoe en To the Light $\mathrm{H}$ ouse de Virginia Wolf.

3. A unque existen estudios que resaltan el aspecto intertextual de este relato, como el de Rennert (1994), titulado “Literary Revenge: Nabokov's “M ademoiselle O" and Kleist Die M arquis von 0 en J ournal of Germanic and Slavic Comparative Studies, que lo compara con una obra alemana, nos vamos a centrar más en el aspecto biográfico de la obra y el juego verdad-ficción que se plantea en el relato.

4. Es interesante el estudio de este autor Nabokov's Art of M emory and European M odernism de 1993 por el análisis intertextual que realiza de este relato de Nabokov con otros escritores de la literatura francesa, como B audelaire o Proust.

5. A pareció primero en las obras autobiográficas: Conclusive Evidence en 1951, después en una versión rusa de la misma obra titulada D rugie B erega en 1954, más adelante en Speak, M emory: An Autobiography Revisited en 1966. Sin embargo, también apareció publicada otra versión del relato en francés en la publicación M esures 1936 antes de la llegada del autor a Estados U nidos. En inglés se leyó en 1943 en The Athlantic Monthly, así como en la colección Nine Stories en 1947 y más tarde en Nabokov's Dozen en 1958. Posteriormente su hijo, D mitri, la incluyó en la colección de relatos Vladimir Nabokov. Collected Stories en 1995. 
B ut of all the windows this is the pane through which in later years parched nostalgia longed to peer. (ND 151)

I could see... celebrating now, in the city of memory, the essence of that spring day. (ND 154)

Como muestran estos ejemplos, el narrador, que es una voz directa del autor, ya que es un relato autobiográfico, habla de su memoria, de su institutriz, de la nostal gia que siente por ese pasado. Durante todo el relato el narrador recuerda su infancia y para ello utiliza prácticamente el pasado o el presente histórico. En estos ejemplos se muestra al narrador que recuerda, que se siente nostál gico y que es consciente de recordar. Según Quennel (1979: 4), el lector puede percibir un cierto sentido de pérdida en toda su obra, pero Nabokov escapa de esa nostalgia del típico emigrante ruso al crear un nuevo mundo, donde el pasado y el presente se reconcilian. A ñadiríamos que otra forma que tiene para escapar de esa nostalgia es problematizando y defamiliarizando las convenciones literarias de las autobiografías para dejarlas expuestas claramente al lector.

Every now and then, she looks back to make sure that a second sleigh, bearing the trunk and hatbox, is following... L et me not leave out the moon - for surely there must be a moon... So there it comes., steering out of a flock of small dappled clouds, which it tinges with a vague iridescence; and as it sails higher, it gazes the runner tracks left on the road, where every sparkling lump of snow is emphasized by a swollen shadow. (ND 145)

But what am I doing there in stereoscopic dreamland? Somehow those two sleighs have slipped away; they have left my imaginary double behind on the blue-white road. (ND 145)

En estos casos, en concreto, el narrador está relatando de una forma convencional la llegada de la institutriz a su casa y, a continuación, se le dirige al lector diciendo lo que tiene que aparecer, como es la luna, que se manifiesta de una forma teatral, resaltando las nubes y creando sombras que destacan en la nieve. Es decir, el narrador está relatando sus memorias, pero el tratamiento que les da es el de ficción y exagera ese tratamiento para que sea evidente para el lector. Tulving (1993: 67) considera "The act of remembering a personally experienced event, that is, consciously recollecting it, is characterized by a distinctive, unique awareness of reexperiencing here and now something that happened before, at another time and place." En este ejemplo el narrador se está mostrando consciente de su acto de rememoración de recuerdos y lo está enfatizando literalmente. Esto tiene que ver con las ideas expuestas por Pillemer (1998: 108) para quien las imágenes de la memoria pueden ser interpretadas conscientemente respecto a su relevancia en las situaciones presentes. Se pueden recordar con un propósito o se 
pueden olvidar, pero, además, considera que "the form of the narrative renditions of events can be manipulated in order to sharpen communicative intent." Esto hace Nabokov, ya que es consciente de que habrá un lector de esta descripción y explicita sus mecanismos conscientemente.

A demás, en el segundo ejemplo deja claro que aparecen dos niveles temporales. Uno es el de la historia que se recuerda y el otro es el de la narración del narrador que es consciente de recordar. El cambio de un nivel a otro se puede apreciar normalmente por cambios de persona y tiempos verbales principalmente. Cuando recuerda el narrador utiliza el pasado y el presente lo utiliza para comentar esos episodios pasados. Son momentos en los que aparece una cierta oposición entre un mundo distanciado temporalmente y el momento particular, cuando un aspecto del pasado se evoca por el narrador.

Hay otros ejemplos en los que se podría deducir que el autor está recordando por los cambios de lugares y momentos, como sucede en el siguiente caso:

M eanwhile the setting has changed. Hoar-frost and snow have been removed. (ND 149)

Otras veces, vuelve a aparecer ese doble fantasmagórico del narrador, que antes se ha citado, que no se trata del niño ruso sino del novelista americano que escribe sus memorias, como sucede también en los ejemplos siguientes:

I can visualize her, by proxy, as she stands in the middle of the station platform, where she has just alighted, and vainly my goshtly envoy offers her an arm that she cannot see. (ND 144)

that great heavenly 0 shining above the Russian wilderness of my past. The snow is real, though, and as I bend to it and scoop up a handful, forty-five years crumble to glittering frost-dust between my fingers. (ND 145)

En el primer ejemplo vemos al escritor ofreciéndole el brazo a la institutriz, que lógicamente no puede ver, al mezclarse dos tiempos distintos, el presente del novelista que le ofrece el brazo y el pasado de la institutriz que acaba de llegar en ese momento. De acuerdo con Rowe (1976: 65), esta técnica de mezclar la memoria pasada y la presente sobre lo recordado hace que la realidad recordada gane más substancia y vivacidad. De esta forma, el autor transciende las limitaciones del tiempo y el espacio y hace que el lector se pregunte quien está escribiendo su propia historia.

En el segundo ejemplos vemos cómo el recuerdo de la nieve a la llegada de la institutriz acaba en la nieve real del escritor americano al cabo de cuarenta y 
cinco años y que es la que realmente le ha traído el recuerdo de la llegada de la institutriz. $^{6}$

En "First Love," por ejemplo, el autor nos cuenta la historia de su primer amor en la costa francesa. Durante la misma el narrador se muestra incapaz de recordar el nombre del perro de Colette. Sin embargo, él mismo comenta que el recreo de los recuerdos de esas playas remotas de la arena del pasado, que ha dibujado en el relato "First Love", le ha llevado a recordar en el penúltimo párrafo su nombre.

And now a delightful thing happens. The process of recreating that penholder and the microcosm in its eyelet stimulates my memory to a last effort. I try again to recall the name of Colette's dog - and, triumphantly, along those remote beaches, over the glossy evening sands of the past, where each footprint slowly fills up with sunset water, here it comes, echoing and vibrating: Floss, Floss, Floss! (ND 50-51)

A Iter (1991: 620) destaca que con este relato Nabokov está rindiendo homenaje a Proust, ya que en la última visión de Colette se dice:

She carried a hoop and a short stick to drive it with...and instantly she was off... around and around a fountain choked with dead leaves near where I stood. The leaves mingle in my memory with the leather of her shoes and gloves, and there was, I remember... (ND 51)

El autor evoca la escena del final de D u côté de chez Swann de M arcel Proust en la que el joven M arcel contempla la figura dorada de Gilberte Swann jugando con las hojas de los campos Elíseos. La conexión entre estos escritores se da al mostrar ambos la recuperación de la experiencia pasada como uno de sus objetivos en las dos obras. En su estudio Alter (1991) considera que ambos escritores siguen procedimientos distintos. Proust piensa que el retorno del pasado está asociado con una memoria involuntaria que actúa en un momento epifánico. $\mathrm{M}$ ientras que para $\mathrm{N}$ abokov esta vuel ta del pasado tiene un aspecto más volitivo, ya que es una consecuencia de la concentración imaginativa que tiene el propósito artístico. Sin embargo, este autor muestra ejemplos en los relatos de Nabokov donde se puede argumentar que, como Proust, considera que el pasado está asociado con la memoria involuntaria, como sucede en al gunos de sus relatos, aunque el propósito del autor sea artístico.

6. Este ejemplo es similar a una escena de A la recherche du temps perdu donde al comer una madalena el personaje recuerda su niñez. 
Este mismo crítico también destaca otros ejemplos. A sí en "The Return of Chorb", al Ilegar Chorb a la entrada de la casa de la niñez de su esposa, ésta le hace recordar:

Beyond the gate, and beyond a dim gravel walk, loomed the front of the familiar house... with one hand he still gripped the wicket and the dewy touch of iron against his palm was the kneenest of all memories. (DS 65)

En "Christmas" cuando el padre está viendo un paisaje cubierto de nieve es capaz de recordar ese mismo paisaje el verano anterior, en el que su hijo iba a cazar mariposas.

A little further, the supports of a foot bridge stuck out of the snow, and there Steptsov stopped. Bitterly, angrily... He vividly recalled how this bridge looked in summer. There was his son walking... with his net a butterfly that had settled on the railing. (DS 155).

Lo mismo sucede en "The Doorbell" cuando el hijo, incapaz de recordar la cara de su madre, al oír su voz en el apartamento donde ahora vive, de repente, recuerda su cara después de haberse separado siete años antes:

Now he tried to picture her face, but his thoughts obstinately refused to take on color (DS 106)... and Nikolay recognized at once that long emphatic " 00 " and on its basis instantly reconstructed down to the most minute feature the person who now stood, still concealed by darkness, in the doorway (DS 107).

Otro ejemplo aparece en "The Reunion", donde dos hermanos se juntan al cabo de diez años y quieren recordar el nombre de un perro con el que estuvieron un verano en su niñez:

"There was a ' $k$ ' in it," replied Lev... It was something like Turk... Trick... No it won't come... The word was still invisible, but its shadow had al ready crept out... his brain ceased straining, the thing stirred again... "Give me your paw, J oker." Joker! How simple it was, Joker... (DS 137-138)

Foster (1993: 84) destaca de este ejemplo que sigue las ideas de Bergson sobre cómo recordamos los nombres. Primero recordamos letras del alfabeto y luego hacemos intentos de pronunciarlo hasta que al final lo decimos.

En general podemos decir que Nabokov pone en práctica en su ficción una característica que reconoce en el trabajo de Proust de su Curso de literatura europea:

En resumen, para recrear el pasado debe tener lugar algo distinto de la operación de la memoria: debe darse la combinación de una sensación actual (especialmente de sabor, olor, tacto o sonido) y un recuerdo, una evocación del pasado actual. (Nabokov 1987: 358) 
Por tanto, los recuerdos se vuelven a evocar con un hecho actual relacionado con los sentidos y la presentación del tiempo pasa a ser una mezcla subjetiva de pasados y presentes. Cabe destacar que este aspecto tiene que ver con las ideas expuestas por B row y K ulik (en Pillemer 1998: 35) cuando dicen: "any event that is shocking and is judged to be highly important or consequential will be recorded initially in sensory rather than narrative form." En los ejemplos mencionados vemos en la primera cita el choque emocional que sufre Chrob con la muerte de su esposa. En la segunda cita el de Sleptsov con la muerte de su hijo y en la tercera cita vemos el choque emocional que supone la unión después de la larga separación de un hijo y su madre, habiendo habido una revolución en medio. A sí vemos que la primera fase de los recuerdos está relacionada con los sentidos, como el tacto o la visión.

L a utilización de $\mathrm{N}$ abokov de un narrador que recuerda en la narración es una característica que ha trabajado en otras obras ficcional es como M ary. B urt Foster (1993: 115) destaca en el autor: "I magination... has outdone memory in recovering the literal truth." De esta forma, el autor utiliza la imaginación para recuperar sus recuerdos y, al aparecer mezclados con su imaginación, muestra aspectos de su vida que no los ve relacionados con él mismo:

Houses have crumbled in my memory as soundlessly as they did in the mute films of yore; and the portrait of my old French governess... is fading fast, now that it is engulfed in the description of a childhood entirely unrelated to my own. (ND 143)

Hay momentos en los que Nabokov reconoce que sus recuerdos han sido materia prima para sus obras literarias. Por eso el novelista dice que ha otorgado algo de su pasado a los personajes de sus novelas.

I have often noticed that after I had bestowed on the characters of my novels some treasured item of my past, it would pine away in the artificial world where I had so abruptly placed it. (ND 143)

A las these pencils, too, have been distributed among the characters in my books to keep fictitious children busy; they are not quite my own now. Somewhere, in the apartment house of a chapter, in the hired room of a paragraph. (ND 147)

En el segundo ejemplo, como vemos, utiliza la metáfora de sus lapiceros de colores que ha distribuido entre los personajes de sus novelas, como si esos lapiceros fueran sus recuerdos. A demás, añade que al prestárselos a sus personajes dejan de ser suyos, precisamente por recuperarlos utilizando su imaginación. También es interesante destacar del segundo ejemplo que une la escritura al exi- 
lio, puesto que habla del apartamento de un capítulo y la habitación alquilada de un párrafo.

Vamos a ver un texto escrito por el joven Sirin de Berlín, donde se refiere a la experiencia de la emigración. También se puede apreciar cómo se siente sobre esa vieja Rusia reconstruida fuera de la tierra natal:

We are the wave of Russia which has left her shores - we are spread over the entire world, but our wanderings are not always in depression, and our courageous longing for our fatherland does not always prevent us from enjoying a strange country... In that particular Russia which visibly surrounds, quickens, supports us, nourishes our souls, adorns our dreams, there is not a single law except the law of love for her, and there is no power except that of our own conscience. (en Field 1967: 183)

M uchas de las obras tempranas de Nabokov tratan de temas rusos, como un sentimiento de nostal gia, la vida en exilio, ironía sobre la situación, una pérdida del sentido del tiempo. De hecho, muchos de los personajes de Nabokov se encuentran perdidos entre las sombras de su pasado y no saben si sus memorias son realidad o ficción. La memoria se mezcla con la fantasía en el intento de llegar a la realidad de la vieja Rusia, pero se encuentra perdida para siempre. Nabokov utiliza esas memorias en su obra y se muestra consciente de ello, no solamente en su autobiografía y los relatos que se desprenden de ella, sino también en las entrevistas que le realizaron y que se encuentran editadas en Strong 0 pinions.

Stegner (1966: 50) y Sicker (1987) consideran que para Nabokov la memoria es uno más de los instrumentos del artista y en "M ademoiselle 0 " el narrador ha podido superar ese tiempo pasado estimulando su memoria al escribir y recordar. En este sentido, el uso de la memoria de Nabokov podría ser comparable a la de Wordsworth para quien la composición de una poesía suponía una "emotion recollected in tranquillity" (A brams 1987: 1299).

Como ya se ha comentado previamente, el narrador de "Mademoiselle 0" sabe que su memoria también reconstruye junto con la imaginación ese pasado. A Iter (1991: 627) afirma: "he has recovered or somehow reconstituted the past in his prose, and that he has rather reinvented a past forever lost in the vanishing perspective of time" y podemos encontrar ejemplos en el relato que muestran esta idea:

A kerosene lamp is steered into the gloaming. Gently it floats and comes down; the hand of memory... places it in the centre of a round table. (ND 146) 
As I reconstruct it now, my mother had probably gone for a few hours to St Petersburg. (ND 147)

En estos ejemplos vemos que es la imaginación la que trabaja la memoria personal. Es lo que hace que, por ejemplo, Clancy (1984: 6) considere a Nabokov el último gran escritor romántico y lo argumenta diciendo: "He shares their belief in the primacy and universality of personal experience which, in turn, involves a concomitant belief in the individual imagination as a primal source of truth." Sin embargo, creemos que el uso que hace Nabokov de la imaginación y de la memoria en su obra no tiene ningún sentido romántico, ya que, como vemos, en estos ejemplos es la imaginación la que substituye a la memoria, pero el narrador se muestra consciente de ello y, al hacerlo, Nabokov no permite que el lector se identifique con los protagonistas, como podría ocurrir en Wuthering H eights, sino que sea consciente del narrador como relator y del proceso de su narración, lo cual es una característica de la literatura postmodernista.

\section{Conclusión}

Nabokov utiliza sus memorias de una forma autoconsciente y las mezcla con la imaginación para conseguir superar el desgaste temporal de un recuerdo, puesto que, como declaró Nabokov (1990: 78): "both memory and imagination are a negation of time". Sobre la importancia de la memoria y la imaginación en N abokov, Burt Foster (1993: 112) comenta: "M emory at one extreme may seem a mere springboard for the supreme freedom of art, but Nabokov can also prefer the exactness of remembered experience to the vague gropings of imagination, while on the same middle ground he realizes that only authorial invention can restore the erasures of time." EI relato de "M ademoiselle 0 " parece estar en medio de este dilema por incluirse en la autobiografía del autor y por formar parte de colecciones de relatos ficticios del autor. De hecho, parece que chocan los intereses de la persona que recuerda y de aquella que narra y recrea esas memorias:

The man in me revolts against the fictionist and here is my desperate attempt to save what is left of poor M ademoiselle. (ND 143)

A I recordar, se mezclan esas memorias con la imaginación y parece que es la imaginación la que guía esas memorias y las recrea. De hecho, en este ejemplo vemos cómo en su relato empieza reconociendo que ha utilizado sus recuerdos en su obra, pero que al recrear sus memorias han perdido autenticidad (R owe 1976: 61). Por esta razón, el hombre que recuerda se rebela contra el que cuenta ficciones para salvar lo que queda de real en la pobre M ademoiselle, ya que, como dice 
Sicker (1987: 265): "Creative recollection... involves the evocation of a past atmosphere and the distillation of its sensory and emotional impact... his discovery... generates another kind of truth. ${ }^{17}$ EI narrador habla de salvar lo queda de verdad de M ademoiselle, puesto que desde el punto de vista de Nabokov la imaginación, que es la que recrea los recuerdos, es una forma de memoria. Sin embargo, también añade algo distinto del original:

I would say that imagination is a form of memory. Down, Plato, down, good dog. A $n$ image depends on the power of association, and association is supplied and prompted by memory. When we speak of a vivid individual recollection we are paying a compliment not to our capacity of retention but to M nemosyne's mysterious foresight in having stored up this or that element which creative imagination may want to use when combining it with later recollections and inventions. In this sense, both memory and imagination are a negation of time. (Nabokov 1990: 78)

La imagen de M ademoiselle 0 se salva del olvido al recrear ese pasado con la imaginación. Por eso la memoria y la imaginación son una negación del tiempo, porque no permiten que en este caso corroan la imagen de $\mathrm{M}$ ademoiselle 0 .

Nabokov muestra su pasado y utiliza los convencionalismos de la autobiografía. Sin embargo, no se muestra nostálgico, ya que a la vez destaca aspectos ficticios que su imaginación crea y los aspectos convencionales que posee la manera autobiográfica clásica de escribir. De esta forma, en este relato opone verdad y ficción para recrear los procesos que sigue la memoria al recobrar un recuerdo cuando lo mezcla con la imaginación. A sí hace consciente al lector de que detrás de esta narración breve hay un narrador consciente de serlo y hace que el lector se identifique con la narración y los procesos narrativos de la misma.

\section{Bibliografía}

A BRAM S, M.H., et al., eds. 1987. The Norton Anthology of English Literature. Nueva York: WW Norton and Company.

ALEXANDROV, Vladimir A, ed. 1995. The Garland Companion to Vladimir Nabokov. Nueva York: Garland Publishing, Inc.

7. En este sentido se puede destacar a Pillemer (1998: 55), al decir que la memoria es un proceso activo, y comentar que "memory desccriptions usual ly are consistent with the general form and content of past experiences, even if particular details are lost, added or distorted in the act of remembering." A unque este crítico, al contrario de Nabokov que habla de la imaginación, no explica cómo sucede. 
ALTER, Robert. 1991. "Nabokov and M emory." Partisan Review 4: 620-629.

BOY D, Brian. 1993. Vladimir Nabokov, The American Years. Londres: Vintage Edition.

CLA NCY, L aury. 1984. The Novels of Vladimir Nabokov. Londres: M acmillan.

FIELD, Andrew. 1967. Nabokov: His Life in Art. Londres: Hodder and Stoughton.

FOSTER, John B urt. 1993. Nabokov's Art of M emory and European M odernism. Princeton, Nueva J ersey: Princeton University Press.

LONG, M ichael. 1984. Marvell and Nabokov: Childhood and Arcadia. Nueva York: Clarendon.

NA B OK OV, V ladimir. 1960. Nabokov's D ozen. 1958. Harmondsw orth: Penguin. A breviado como ND.

- 1987. Curso de literatura europea. 1980. Barcelona: ediciones G rupo Z.

- 1990 Strong O pinions. 1973. Nueva York: M cGraw-Hill B ook Company.

- 1994. Details of a Sunset and O her Stories. 1976. Harmondsworth: Penguin. A breviado como DS.

NICOL, Charles, y BARABTARLO, Gennady. 1993. A Small Al pine Form. Studies in Nabokv's Short Fiction. Nueva Y ork: Garlaand Publishing, Inc.

NICOL, Charles, y J.E. RIVERS. 1982. Nabokov's Fifth Arc. A ustin: University of Texas Press.

PILLEMER, David B. 1998. Momentos Events, Vivid Memories. Londres: Harvard U niversity Press.

QUEN NELL, Peter, ed. 1979. H is Life, His Work, H is World: Vladimir Nabokov. A Tribute. L ondres: Weidenfeld \& Nicolson.

ROTH, Phyllis A . 1982. "Toward the M an behind the M ystification." En Nicol y Rivers 1982: 43-59.

ROWE, William Woodin. 1971. Nabokov's Deceptive World. Nueva York: New York UP.

- 1976. "Nabokovian Superimposed and Alternative Relaities." Russian Literature Triquaterly 14: 59-66.

SHL OSS, Carol. 1982. "Speak, Memory: The A ristocracy of A rt." En Nicol y Rivers 1982: 224-229.

SICK ER, Philip T. 1987. "Practicing Nostal gia: Time and M emory in Nabokov's Early Russian Fiction." Studies in Twentieth Century Literature 11.2: 253-270.

STEGNER, Page. 1966. Escape into Aesthetics. The Art of Vladimir Nabokov. Nueva York: The Dial Press.

TOLSTAIA, Natalia, y MEILAKH, Maxim. 1995. "Russian Short Stories." En A lexandrov 1995: 644-660.

TULVING. 1993. "What is episodic memory?" Current Directions in Psychological Science 2: 67-70. 